\title{
Melatonin and its importance
}

\author{
Rabia Serpil GÜNHAN *1 \\ ORCID: 0000-0001-6360-8185
}

\author{
${ }^{1}$ Konya Technical University, Vocational of Technical Sciences, Food Technology, 42100, Konya, Turkey
}

\begin{abstract}
Melatonin is the essential hormone that is regularly secreted by the pineal gland of mammals on a dailybasis. Melatonin is involved in many chemical, biological and physiological bio activity period in the body. The main task of melatonin is to preserve the biological clock known as 'jet lag' and to adjust its rhythm. Melatonin has antioxidant enzymes stimulating, reducing lipid peroxidation, protecting brain tissue from oxidative damage. In addition, it has properties that inhibit the proliferation of cancer cells and tumor growth. Melatonin is a compound highly soluble in water and oil. Melatonin, a bioactive compound, is found in oranges, tomatoes, strawberries, grapes, cherries, oliveoil, rice, barley and walnuts and in some medicinal and aromatic plants that constitute the source of functional food and pharmaceutical raw materials consumed for health.. The purpose of this review is to contribute to healthy nutrition and life by examining studies investigating the importance of melatonin, its functional properties, profile in foods, and the effect of food processing on melatonin content.
\end{abstract}

Keywords: Melatonin, food, health

Melatonin ve önemi

\section{Özet}

Melatonin memelilerin pineal bezi tarafindan günlük olarak düzenli şekilde salgılanan temel hormondur. Melatonin, vücutta birçok kimyasal, biyolojik ve fizyolojik faaliyette yer almaktadır. Melatoninin asıl görevi 'Jet lag' olarak bilinen biyolojik saatin korunması ve ritminin ayarlanmasıdır. Melatonin antioksidan enzimleri uyarıcı, lipit peroksidasyonunu azaltıcı, beyin dokusunu oksidatif hasardan koruyucu etkiye sahiptir. Ayrıca kanser hücrelerinin çoğalmasını, tümör büyümesini engelleyici özellikleri bulunmaktadır. Melatonin suda ve yağda çözünürlüğü oldukça yüksek bir bileşiktir. Biyoaktif bir bileşik olan melatonin; portakal, domates, çilek, üzüm, kiraz, zeytinyağı, pirinç, arpa, ceviz ve sağlığa yönelik tüketilen fonksiyonel gıda ve ilaç hammaddelerinin kaynağını teşkil eden bazı tıbbi ve aromatik bitkilerde farklı bileşimlerde bulunmaktadır. Bu derlemenin amacı melatoninin önemi, fonksiyonel özellikleri, gıdalardaki profili ve gıda işlemenin melatonin içeriğine etkisi konularını araştıran çalışmaları inceleyerek sağlıklı beslenme ve yaşama katkı sağlamaktır.

Anahtar kelimeler: Melatonin, gıda, sağlık

\section{Giriş}

Melatonin (N-asetil-5-metoksitriptamin) doğada, tüm canlı organizmalarda bulunan özellikle omurgalılar ve memelilerde epifiz bezinde üretilen ve direkt kana geçen bir hormondur [1]. Epifiz bezinin bir nöro hormonu olarak çalışmaktadır. Ayrıca retina ve gastrointestinal sistem gibi birçok hücre ve dokuda da üretilmektedir [1;2]. Melatoninin varlığ 1958 yılında dermatolog Lerner tarafından tespit edilmiştir. Hipofizden elde ettiği bu hormonun cilt rengini

\footnotetext{
* Corresponding author / Haberleşmeden sorumlu yazar: Tel.: +03322410104; Fax.: +03322410185; E-mail: rsgunhan@ktun.edu.tr

(C) Copyright 2021 by Biological Diversity and Conservation Geliş tarihi29.07.2021; Yayın tarihi: 15.08.2021 BioDiCon. 984290721
} 
açmasından dolayı bu maddeye, Latince siyah anlamına gelen "melas" ve iş anlamına gelen "tosos" kelimelerini birleştirerek "melatonin” adını vermiştir (Şekil 1) [3].

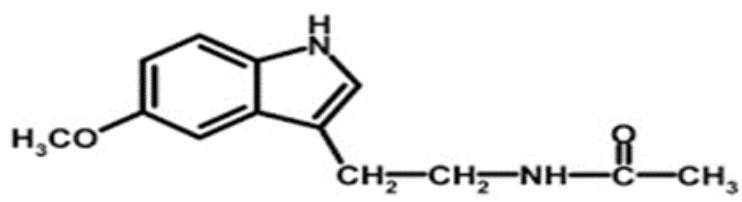

Şekil 1. Melatonin (N-acetyl-5-methoxytryptamine) (3)

Melatonin, insan biyokimyasal metabolizmaları ve fizyolojik ritmini düzenleyen, jet lag ve uykusuzluk gibi ilgili bozuklukları hafifleten, serbest radikal süpürücü ve bağışıklık sistemini güçlendiren bir hormondur. Yaşlanma karşıtı, ve kansere karşı koruyucu etkileri mevcuttur. Ayrıca melatonin, sinir koruyucu etkiler de bulunmaktadır. Kalp, diyabet ve obezite gibi kronik hastalıkların kontrolünde önemli etkilere sahiptir [4]. Küresel melatonin pazarı 2018'de 700 milyon ABD Doları değerindedir ve 2025 yılına kadar 2.790 milyon ABD Doları'na ulaşacağ beklenmektedir [1].

Melatonin analizi için birçok yöntem uygulanmıştır. Bu yöntemler arasında floresan (FL) ile yüksek performanslı sıvı kromatografisi (HPLC), kütle spektrometrisi (MS), gaz kromatografisi ve kütle spektrometresi (GCMS) radyoimmunoassay (RIA), enzime bağlı immünosorbent deneyi (ELISA), immunkromatografik yöntemler (ICA) ve immünopresipitasyon sayılabilmektedir [5]. Birçok hayvansal ve bitkisel kökenli gıdalarda melatonin pg/g veya $\mathrm{mg} / \mathrm{g}$ arasında değişen miktarlarda analiz yapılmaktadır. Melatonin açısından zengin gıdaların tüketimi, insanlarda serum melatonin konsantrasyonunu ve antioksidan kapasitesini önemli ölçüde artırmaktadır [6].

$\mathrm{Bu}$ derlemede melatoninin tüm fonksiyonel özellikleri baz alınarak sağlık üzerine etkileri ve son literatürler 1şığında özellikle melatoninin önemi, melatonince zengin gıdaların vurgulanması ve sağlıklı yaşam için sağlıklı beslenmeye destek olunması amaçlanmıştır.

\subsection{Melatonin Fonksiyonlarl}

Melatoninin en önemli fonksiyonları anti-oksidatif (antioksidan) özellikleri, metabolizma düzenleyici,

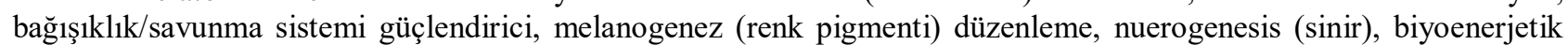
(enerji) düzenleme, antiinflamatuar (enflamasyon/ödem azaltan) özellikler, uyku düzenleme, sirkadiyen (peryodik davranışlar) ritim düzenleme, onkostatik (tümör gelişimini engelleyen) özelliklerdir [7, 2]. Melatonin kardiyolojik hastalıkların önlenmesinde etkili bir bileşiktir. Melatonin güçlü bir kardiyoprotektandır ve düşük dozlarda verildiğinde bile kardiyolojik yaşlanma üzerinde ve diğer birçok bozuklukta faydalı etkiler göstermektedir [8; 9].

Melatonin, ruh halinin düzenlenmesinde rolü vardır. Uyku ve uyanma döngülerini ve üremeyi düzenlemektedir [5]. Ayrıca kaygıyı azalttığı ve bağışıklığı uyardığı bilinmektedir. Oksidatif strese karşı en doğal antioksidandır. Melatoninin, Dünya Sağlık Örgütünce (DSÖ) tarafindan pandemik hastalik ilan edilen korona virüsün (Covid-19) sebep olduğu çeşitli hastalık semptomlarını önleme veya azaltmada özellikle yaşlı insanlarda etkili olabileceği belirtilmektedir [10]. Uyku sorunu olan kişilerde, hızlı göz hareketleri (REM) düzensizliğinde, huzursuz bacak sendromunda, gecikmiş uyku fazı sendromunda, uyku sorunu olan manik kişilerde ve fibromiyaljisi olanlarda melatoninin kullanılmasının uyku süresini ve kalitesini arttırdığı bildirilmiştir. Dikkat eksikliği/hiperaktivite ve uyku başlangıcında bozukluğu (sleeponset insomnia) olan çocuk hastalar içinde etkili olduğu belirtilmiştir. Melatonin düzeyi ile depresyon arasında bağlantı vardır. Antidepresanlar, norepinefrin ve serotonin düzeylerini arttırarak melatonin miktarını da arttırmaktadırlar [11].

Epifiz bezi vücudun "biyolojik saati" olarak kabul edilir ve melatonin bu bezin başlıca salg1 ürünüdür. Melatonin, vücuttaki birçok süreçte, özellikle sağlıklı yaşlanmada ve serbest radikallere bağlı hastalıkların önlenmesinde önemli bir rol oynamaktadır. Melatonin, endojen bir senkronizör olarak diğer hormonal ritimlerin düzenlenmesini etkiler. Yaşlanma ile melatonin üretimindeki azalma ve değişen melatonin ritimleri, engellenmiş bir bağışıklık sistemine yol açabilmektedir. Bu değişiklikler yaşlılarda hastalık riskinde artışa neden olmaktadır [12].

Melatonin lipofilik ve hidrofilik özelliktedir. Dolayısıyla suda ve lipid fazda çözünebildiğinden tüm intra selüler komponentlere rahatlıkla geçip hücre zarını, organelleri ve çekirdeği etkin bir şekilde serbest radikal hasarından koruyarak potansiyel bir antioksidan etki göstermektedir. Ayrıca, serbest radikal süpürücü etkisi için spesifik bir bağlanma bölgesi veya reseptör gerekmemektedir. Melatoninin bu rolünün sağlık üzerine etkisi ile ilgili birçok çalışma yayınlanmıştır [12; 13].

Melatoninin tümör gelişimini baskıladı̆̆ı bilinmektedir. Melatonin salınımının bozulması, artan kolorektal kanser insidansı ile bağlantılıdır. Ayrıca melatonin, gastrointestinal sistemde çeşitli kanserlerin önlenmesiyle de ilgilidir [19]. Melatoninin kanseri engellemesi vücudun antioksidan kapasitesini artırarak ve apopitoz adı verilen hücrelerin programlı ölümüne yardımcı olarak gerçekleştiği belirtilmektedir [11]. 
Enflamatuar bağırsak hastalıkları arasında Crohn hastalığı ve ülseratif kolit gastrointestinal sistemin kronik bozukluklarıdır. Melatoninin, irritabl bağırsak sendromu, Crohn hastalığı, ülseratif kolit ve nekrotizan enterokolit dahil olmak üzere çeşitli gastrointestinal hastalıklara karşı koruyucu etkileri mevcuttur [14].

Viral enfeksiyonlar genellikle, oksidatif stres seviyesinin önemli ölçüde arttığı ve birden fazla organın işlevi üzerinde olumsuz etkilere sahip olduğu immün inflamatuar hasar ile ilişkilidir. Melatonin, çeşitli biyolojik süreçlerde anahtar rol oynar ve viral enfeksiyonların yönetiminde alternatif bir bakış açısı sunmaktadır. Melatonin, antienflamatuar ve antioksidan etkileri nedeniyle viral replikasyonu veya transkripsiyonu yok edemese ve hatta engelleyemese de, melatonin, antiviral tedavide hastaların klinik semptomlarını hafifletmek için aday bir ilaç olarak önerilmektedir [15; 12]. Kısacası Melatonin virisidal özelliklere sahip değildir; bununla birlikte, anti enflamatuar, antioksidan ve bağışıklık artırıcı etkiler yoluyla dolaylı antiviral etkiye sahiptir [16].

Çeşitli çalışmalardan elde edilen kanıtlar, triptofan ve melatoninin enflamatuar reaksiyonları azaltabileceğini ve bağışıklık sistemini güçlendirebileceğini göstermiştir. Ayrıca, COVID-19 hastalarında serotonin düzeylerinin zihinsel stres nedeniyle değişmektedir, bu durum da triptofanın tedavide bir rolü olduğunu düşündürtmektedir. Triptofan ise, çeşitli fizyolojik yollarla bağışıklık sistemi üzerinde faydalı etkiler yarattığı bildirilen melatonin (uyku hormonu) için öncü bir aminoasittir [17]. Melatoninin COVID-19 ile enfekte hastalar için bir koruyucu tedavi olarak klinik deneylere dahil edilmesi istenmektedir. Yüksek etkinliği ve kanıtlanmış güvenliği ile ilgili bilimsel kanıtlar doğrultusunda, melatoninin COVID-19 enfeksiyonuna karşı potansiyel rolünün test edilmesi için çalışılmaktadır [7].

İnsanlarda gıda alımı ile melatonin konsantrasyonlarının yükselmesi glukoz toleransını azaltmaktadır. Vardiyalı çalışanlar, gece yiyenler ve melatonin kullanıcıları, gıda alımının ve yüksek melatonin seviyelerinin aynı anda ortaya çıkmasının getirdiği olumsuz etkilere karşı hassastırlar. Tip2 diyabet hastalığının teşhisi, önlenmesi ve tedavisi için klinikte dikkate alınması gereken yeni bir faktör olarak zamanlama önerilmektedir. Ayrıca zamanlama epidemiyolojik, klinik ve temel araştırmalardaki karışıklığı ve görünen çelişkileri çözmeye yardımcı olabileceği belirtilmektedir [4].

Melatonin bitkilerde büyüme ve gelişim düzenleyici olarak da dikkate değer öneme sahiptir. Antioksidan etki göstererek bitkilerde çevresel faktörlere karşı tolerans artırması, klorofili koruması ve kök yenilenmesini desteklemesi gibi etkileri mevcuttur [18]. Bitki fizyolojisinde melatonin rolü ile ilgili birçok çalışma mevcuttur. Melatonin, abiyotik stres faktörlerine (tuzluluk, kuraklık, akut sıcaklık değişiklikleri, yoğun UV radyasyon ve toksik kimyasal maddeler) ve biyotik streslere (mikrobiyal enfeksiyonlar) karşı antistres ajan olarak görev yapmaktadır. Ayrıca melatonin, bitki büyümesi ve fotosentezinde rol oynamaktadır [5].

Melatoninin koyun sütü kimyasal bileşimine etkisi ile ilgili çalışmada, süt bileşenlerini etkilediği, laktozun azaldığı, süt yağ asitlerinin önemli oranda değiştiği, kontrol grubuna göre arttığı belirtilmiştir [19].

Melatoninin tarımda uygulanması ile ilgili çalışmada, melatonin hasat sonrası hünnap meyvesinin aşırı olgunlaşmasını geciktirdiği, meyvedeki pestisit bozunmasını artırıcı etki gösterdiği ve antioksidan birikiminin düzenlenmesinde olumlu etkisi olduğu tespit edilmiştir [20].

\subsection{Melatonin Biyosentezi ve Kaynaklart}

Melatonin, memelilerin öncelikle pineal bez olmak üzere over, lens ve kemik iliği hücreleri ile safra ve mide bağırsak sisteminden sentezlenip salınan bir hormondur [21]. Protein amino asitlerinden triptofan melatonin sentezinde öncü bir madde olup pineal bezi tarafindan plazmadan alınır. Triptofan besinlerle dışarıdan alınması gereken esansiyel bir aminoasittir [22]. Triptofan, triptofan hidroksilaz ile 5-hidroksitriptofan'a hidroksillenmektedir. Triptofan hidroksilaz enzimi, serotonin üretim yolağının ilk enzimidir ve hız kısıtlayıcı rolü vardır. B6 vitamini koenzim olarak bu reaksiyonda görev yapmaktadır. Oluşan 5-hidroksitriptofandoğal olarak ortaya çıkan bir ara metabolittir. 5hidroksitriptofan kan-beyin bariyerini kolayca geçebilir. 5-hidroksitriptofan, L-amino asit dekarboksilaz enzimi aracılığıla karboksil grubunu kaybederek serotonine dönüşür. Seratonin kan-beyin bariyerini geçemez. Serotonin daha sonra N-asetiltransferaz (NAT) enzimi aracılığg ile asetillenerek $\mathrm{N}$-asetilserotonin'e dönüşür. $\mathrm{N}$-asetilserotonin ise hidroksiindol-O-metil-transferaz ile melatonine dönüşür (Şekil-2) [11;3]. 


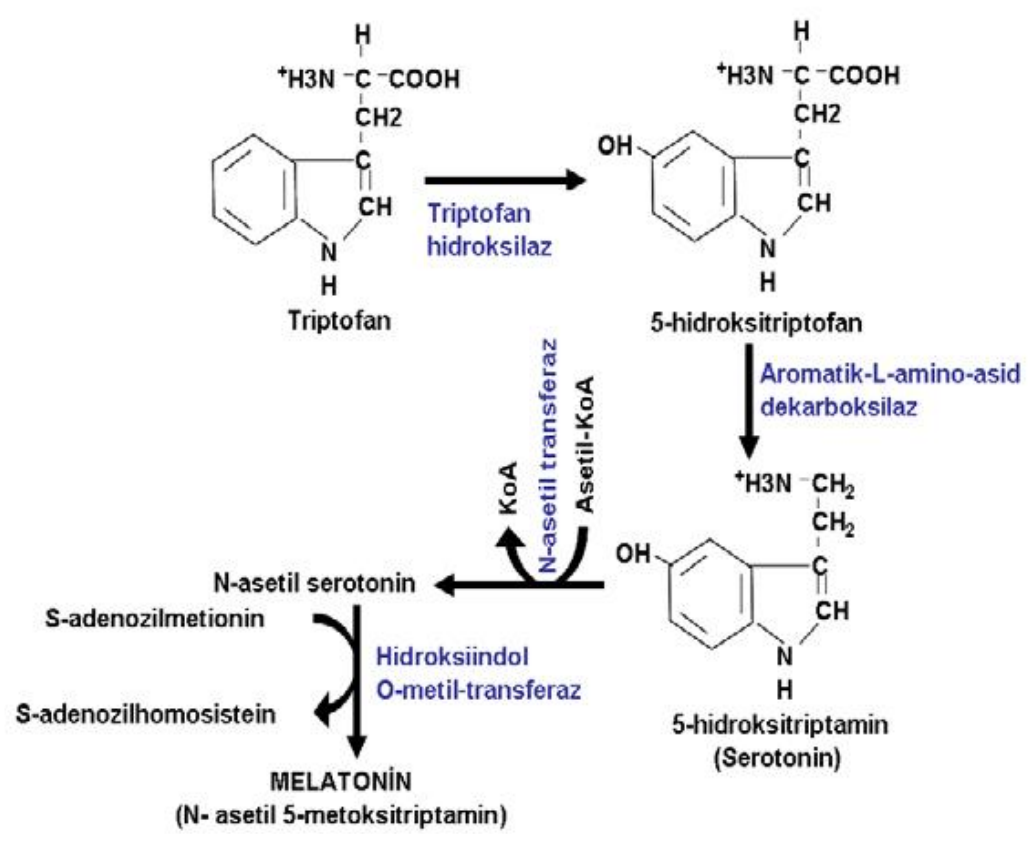

Şekil 2. Melatonin Sentezi [11]

Melatonin geceleri normal ışık veya karanlık koşullarda epifiz bezi tarafından sentezlenerek salgılanmaktadır. Bir amino asit öncüsü olan L-triptofandan, çeşitli enzim bazlı reaksiyonların bir kademesinde üretilir [5]. Melatoninin sentezi ve salınmasını etkileyen birçok faktör vardır ancak en önemli faktör 1şıktır [3, 21]. Akşam hava karardıktan sonra, melatonin salgısı artmaya başlar, gece en yüksek noktasına ulaşır, sabah gün ışığının artmasıyla salgısı azalır. Melatoninin kanda ve hücre içinde gece konsantrasyonları gündüze göre 3-10 kat daha fazla olduğu belirtilmektedir [3]. Beslenme faktörleri de melatonin üretimini etkilemektedir. Diyetin etkisi, melatonin sentezinde kofaktör ve aktivatör olarak hareket eden belirli vitamin ve minerallerle bağlantılıdır. Bu nedenle, bazı besinlerdeki eksiklik, dahili kaynaklı (endojen) melatonin sentezini kısitlayabilir.

Melatonin birçok gıda kaynağında bulunmakla birlikte melatonin içeriği gıdalara göre çok farklılıklar göstermektedir. Harici (eksojen) olarak diyetle alınan en zengin melatonin kaynakları yumurta, balık, bazı mantarlar, arpa, yulaf, çimlenmiş tohum, sert kabuklu yemişler, tıbbi bitkiler gibi ürünlerdir [23]

Melatonin eksikliğini önlemek için gıda takviyesi şeklinde veya gıda ile dışarıdan alınmalıdır. Genelde gıda takviyeleri 1 ile $5 \mathrm{mg}$ arasında melatonin konsantrasyonu içermektedir. Amino asitler açısından zengin meyve yan ürünleri (prina) gibi mikroorganizma büyümesi için yenilenebilir besin kaynaklarının kullanılması, atıkların azaltılmasına katkıda bulunarak atmosfere sera gazı emisyonlarını kısmen azaltacaktır. Biyoteknolojik bir yaklaşımın kullanılması yoluyla \%100 doğal ve çevre dostu melatonin üretimi, kimyasal olarak sentezlenmiş melatonine iyi bir alternatif olabileceği belirtilmektedir [1].

Doğadaki tüm hayvanlar, bitkiler ve insanlar bir dengenin ürünüdür [24]. Bitkilerin tohumları, kökleri, yaprakları ve meyveleri iyi bir melatonin kaynağı olduğunu çalışmalar göstermektedir. Melotonin seviyesindeki değişiklik bitkinin çeşidine, iklim koşullarına, bahçecilik uygulamalarına, işleme ve depolama şartlarına göre değişmektedir [5].

Turp bitkisi, beyaz dut yaprağı, buğday tohumu, asya pirinci, hünnap bitkisi, ahududu bitkisi, hlamur yaprağ ve aleovera gibi bitkilerde melatonin düzeyleri sırasıla 485; 1510;124.7; 1006; 256; 387; 410 ve 516 ng/g olarak belirtilmiştir [25]. Hypericum perforatum (çiçekleri), Tanacetum parthenium (çiçekleri), Piper nigrum L. (meyveleri) gibi tıbbi bitkilerde melotonin düzeyi sırasıyla 4490; 1920-2450; 1092.7ng/g kuru madde olarak rapor edilmiştir [23].

Kiraz, çilek, kivi, elma, üzüm, muz, ananas, koyu yeşil sebzeler ve Japon sebzeleri gibi melatonin kaynakları olan çeşitli gıdalar insanlarda melatonin seviyelerinde gelişmelere katkıda bulunarak sağlığın korunmasına katkıda bulunduğu belirtilmektedir. Bu meyvelerde yenilebilir tohumlara göre daha az melotonin içermektedir [5]. Melatonin düzeyi ortalama olarak ananasta; $302 \pm 27 \mathrm{pg} / \mathrm{g}$, muzda; $8.9 \pm 0.3 \mathrm{pg} / \mathrm{g}$ ve portakalda; $150 \pm 4 \mathrm{pg} / \mathrm{g}$ tespit edilmiştir. Bu meyveleri tükettikten iki saat sonra serum melatonin düzeyinin de arttığ belirlenmiştir [26].

Domates ve çilek çeşitlerinde melatonin düzeyi sırasıyla $4.11 \mathrm{ng} / \mathrm{g}-114.52 \mathrm{ng} / \mathrm{g}$ (taze ağırlık); $1.38 \mathrm{ng} / \mathrm{g}$ 11.26ng/g (taze ağırlık) olarak belirlenmiştir. Ayrıca domates ve çilekte melatonin yeni bir biyoaktif bileşik olarak görülmüştür [27]. Farklı meyvelerde melatonin düzeyi farklı olduğu gibi, aynı meyvenin farklı varyetelerinde de farklı olmaktadır. Bu farklılık, meyvenin büyüme durumu, konumu, çevresel stres ve analitik yöntemi gibi birçok hipotezleri dahil edilerek açıklanmıştır [28]. Altı farklı tropikal meyvede (mango, papaya, ananas, muz, portakal ve makmao) sirasıyla $699 \pm 75 ; 241 \pm 15 ; 302 \pm 47 ; 8.9 \pm 0.6$ ve $150 \pm 6 \mathrm{pg} / \mathrm{g}$ melatonin tespit edilmiştir [29]. 
Meyvelerde melatonin, üzüm ve türevleri (şarap ve meyve suyu), kiraz, çilekve kivi en yüksek konsantrasyonlara sahiptir. Sebzeler arasında melatoninin ana kaynakları biber, domates ve mantardır [30]. Kırmızı dolma biber ve turuncu dolma biber de metanol ile ekstraksiyonunda melatonin düzeyini HPLC- MS ile miktar tayininde sırasıyla; $179.5 \mathrm{pg} / \mathrm{g}$ ve $581.1 \mathrm{pg} / \mathrm{g}$ olarak tespit edilmiştir [31].

Türkiye de yetiştirilen vişne çeşitlerinde, vişne suyu ve konsantratlarında melatonin düzeyleri araştırılmıştır. Vişne meyvesinde en fazla melatonin $(13.80 \mathrm{ng} / \mathrm{ml})$ tespit edilirken vişne suyunda ve vişne suyu konsantratında melatonin belirlenememiştir. Bu durum melatoninin kararsız olduğundan proses ve depolamadan sonra degradasyona uğradığı ile açıklanmıştır [31].

Araştırmacılar, şaraplarda melatonin varlığını ve mayanın melatonin konsantrasyonu üzerindeki etkisini kesin olarak kanıtlamışlardır. Melatoninin, üzümlerde ve şıralarda bulunmadığını ve alkol fermantasyon işlemi sırasında sentezlendiğini tespit etmişlerdir. Hem beyaz hem de kırmızı şaraplarda, maya ilavesinden sonra ve fermantasyon sırasında melatonin konsantrasyonunun arttığı belirtilmiştir [32].

Uyku kalitesini geliştirmek için melatonince zengin gıdaları tüketmek oldukça önemlidir. Melatonin kaynakları olan süt ve vişne tüketiminin uyku kalitesini artırdığı bildirilmektedir [30]. Triptofanla zenginleştirilmiş gece sütü katkılı süt ile beslenen ratlarda uyku kalitesinin geliştiği gözlemlenmiştir [33].

Bitkisel kökenli melatonin (fitomelatonin) (N-asetil-5-metoksitriptamin) için kullanılan terimdir. Fitomelatonin çok çeşitli sebzelerde, tohumlarda, meyvelerde, sert kabuklu yemişlerde ve aromatik / şifalı bitkilerde tespit edilmiştir. Genellikle bitkilerdeki daha yüksek fitomelatonin seviyeleri, hem fiziksel (UV radyasyonu, yüksek veya düşük sıcaklıklar, yüksek basınç) hem kimyasallar (tuzluluk, alkalite, su açı̆̆ı, ağır metaller, herbisitler, reaktif oksijen türleri, diğer kimyasallar) gibi doğal veya yapay stresörlerin varlı̆̆ ile ilgilidir [34]. Dut (Morus spp.) yaprakları (335.5 ng/g DW melatonin) ve dut yaprağı çayında önemli oranda melatonin tespit edilmiștir. Ayrıca melatonin düzeyi üzerine, örnek hazırlama, çeşit, yaprak yaşı ve çay işlemenin etkileri olduğu belirtilmiştir [35].

Hayvansal kaynaklardan yumurta ve balıkta kırmızı etten daha fazla melatonin olduğu tespit edilmiştir. Tavuk ciğeri, tavuk eti, kuzu eti, sığır eti, domuz eti, somon balı̆̆ı ve kurutulmuş yumurtada melatonin düzeyini sırasıyla 1.1; $2.3 ; 1.6 ; 2.1 ; 2.5 ; 3.7$; ve $6.1 \mathrm{ng} / \mathrm{g}$ olarak belirtilmiştir [36].

Anne sütü ve diğer içme sütlerinde de melatonin mevcuttur. Gece sağılan inek sütlerinde melatonin oranı gündüz sütüne göre on kat fazla olduğu belirtilmiştir [33]. Sütteki melatonin düzeyini katı faz ekstraksiyonu ve LCMS / MS tandem kütle spektrometresi kullanılarak belirlenen çalışmada inek sütü ve anne sütünde sırasıyla melatonin düzeyi; $14.57,16.52(\mathrm{pg} / \mathrm{mL})$ olarak bulunmuştur [13].

Sütteki melatonin düzeyine mevsimlerin, gündüz akşam sağılmasının etkisini inceleyen çalışmalarında [37] melatonin ortalama konsantrasyonu inek sütünde $6.98 \mathrm{pg} / \mathrm{mL}$, bulk tank sütünde $4.71 \mathrm{pg} / \mathrm{mL}$ ve UHT sütünde $5.62 \mathrm{pg}$ / mL olarak belirlemiş̧lerdir. Gece sütünde melatonin konsantrasyonu ortalama $14.87 \mathrm{pg} / \mathrm{mL}$, günlük sütte $6.98 \mathrm{pg}$ / $\mathrm{mL}$ tespit edilmiş ve kış sütünün melatonin konsantrasyonu, yaz mevsimine göre ortalama \%74,7 daha yüksek olduğu sunucuna ulaşılmıştır.

Buğday, yulaf ve arpa gibi bazı tahılların melatonin düzeyleri, sırasıyla $14.9 \mathrm{ng} / \mathrm{g}, 7.7 \mathrm{ng} / \mathrm{g}$ ve $6.0 \mathrm{ng} / \mathrm{g}$ olarak belirtilmiştir [10]. Ek takviye veya diyetle melatonin alımının artması yaşa bağlı dejeneratif durumları geciktirmede faydalı olduğu görülmektedir. Buğday, çavdar veya kavuzlu unlar kullanılarak formüle edilen ekmeklerde melatonin düzeyi MS / MS'ye bağlı mikro-HPLC kullanılarak tespit edilmiştir. Sonuçta en iyi melatonin kaynağının karışık buğday-çavdar ekmeği ve ardından çavdar ekmeği olduğu belirtilmiştir [38].

Yapılan çalı̧̧mada [39], ceviz, kavrulmamış kahve, kakao tozu, domates, probiyotik yoğurt, sızma zeytinyağı, ekmek içi, ekmek kabuğu ve birada melotonin miktarını sırasıyla 137.9; 39.0; 7.2; 28.9; $126.7 ; 5.3 ; 341.7 ; 138.1$ ve 94.5 $(\mathrm{pg} / \mathrm{g}$ veya $\mathrm{pg} / \mathrm{ml})$ olarak belirlenmiştir. Yeşil çay, siyah çay, vişne ve kefir de ise melatonin bulunmamış ancak farklı düzeyde melatonin izomerleri tespit edilmiştir.

Araştırıcılar [40], kahve tanelerindeki melatonin düzeyi incelemesinde, kahve çeşidinin ve kahve kavrulmasının melatonin düzeyini etkilediğini belirtmiştir. Coffea arabica tür kahvenin çiğ ve kavrulmuşunun Coffea canephora kahve türünden melatoninin daha fazla olduğunu tespit etmişlerdir. Çiğ kahvede melatonin (C. arabica) 6.8 $\pm 0.4 \mu \mathrm{g} / \mathrm{g}$ iken kavrulmuş kahvede (C. arabica) $9.6 \pm 0.8 \mu \mathrm{g} / \mathrm{g}$ olarak ölçülmüşsür.

Cevizde ortalama melatonin miktarı $3.5 \pm 1.0 \mathrm{ng} / \mathrm{g}$ olarak bulunmuştur [41]. Kırmızı biber ve domateste melatonin düzeyi 31.0- $93.4 \mathrm{ng} / \mathrm{g}$ ve $7.47-249.98 \mathrm{ng} / \mathrm{g}$ olarak belirtilmiştir [42].

Çin tıbbi bitkilerin melatonin düzeyi ile ilgili çalışmada birçoğunun melatonin düzeyi $1000 \mathrm{ng} / \mathrm{g}$ üzerinde olarak tespit edilmiştir. Çalışmadaki bitkilerden en fazla melotonin içeriği sırasıyla Periostracum cicadae, Viola philipica Cav., Uncariarhynchophylla, Babreumcoscluea, Morus alba L (Leaf), Phellodendronamurense Rupr., Mori Albae (Cortex), Epimedium brevicornum Maxim, Coptis chinensis Franchen melotonin içeriği sırasıyla 3,771; 2,368; 2,$460 ; 2,120 ; 1,510 ; 1,235 ; 1,110 ; 1,105 ; 1,008 \mathrm{ng} / \mathrm{g}$. olarak bulunmuştur [6].

\section{Gıda İşlemenin gıdalardaki melatonin düzeyine etkisi}

İnsanlar tarafından yüksek oranda tüketilen yenilebilir tohumlar melatoninin ana kaynağı olarak kabul edilmez. Pişirme işlemleri sırasında melatonin stabil durumunu koruyamaz ve zarar görür [1]. Meyvelerin isıl işlem görmeden 
çiğ tüketilmesi ve antioksidanlar (örn; askorbik asit, karatonenoidler) içermesi nedeniyle melatoninin parçalanmadan alımını sağlamaktadır [5].

Gıda proses veya depolama sırasında melatonin düzeyinde değişiklik olmaktadır. Yapılan araştırmada, meyve sularında (elma suyu, lychee suyu, guava suyu, domates suyu ve portakal suyu) pH, işık ve sıcaklığın melatonin düzeyine etkisini araştırmışlardır. Ph arttıkça melatoninin azaldığını ve yüksek sıcaklık ve ışık varlığında melotoninin degradasyonunun arttığını belirtmişlerdir [43].

Üzüm ve şaraplarda melatonin düzeyi farklı bulunmuştur. Önemli maya türlerinden Saccharomyces cerevisiae şarap prosesinde melatonin oluşumu için ana faktördür. Nar suyunda melatonin yok iken nar şarabında tespit edilmiştir. Birada alkol oranı arttıkça melatonin düzeyinin arttığ1 görülmüştür. Bu durum melatoninin alkolde çözünürlüğü ile açıklanmıştır. Saccharomyces cerevisiae mayasının melatonin sentezinde oldukça önemli olduğu ve şarap üretiminde fermantasyon sırasında kullanılan farklı şarap maya suşlarının da melatonin sentezinde etkili olduğu belirtilmiştir [44, 45]. Farklı tür narlardan üretilen şaraplarda melatonin düzeyi de farklı olup 0.54-5.50 ng/ml aralığında bulunmuştur. Ayrıca şarap yapım prosesinin melatonin düzeyini etkilediği belirtilmiştir [46]. Şarap yapımında alkol ve malolaktik fermentasyon melatonin ve melatonin izomerlerinin düzeyini etkilemektedir. Bu durum fermentasyon sürecindeki farklı mikroorganizma kullanımının etkisiyle açıklanmaktadır. Ayrıca melatonin ve izomerlerinin verimlerini laboratuvar ve şaraphane ölçeklerinde farklılık gösterdiği ve diğer faktörlerin de (yani şarapçılık uygulamaları, polifenol içeriği, mikrobiyal büyüme inhibitörleri ve arttırıcılar, vb.) indolamin türevlerinin sentezini etkilediği belirtilmektedir [1].

Yapılan çalışmada [47], portakal suyundan düşük alkollü içecek geliştirilmiş ve Saccharomycetaceae türü Pichia kluyveri gibi maya suşunun fermentasyon koşulları altında melatonini yüksek konsantrasyonlarda sentezleyebildiği gözlemlenmiştir. Melatonin miktarının alkol fermentasyonu sırasında $3.15 \mathrm{ng} / \mathrm{ml}$ 'den 15 gün sonra $21.80 \mathrm{ng} / \mathrm{ml}$ 'ye arttı̆̆ 1 belirtilmiştir. Melatonin izomerleri $11.59 \mathrm{ng} / \mathrm{ml}$ 'den $14.18 \mathrm{ng} / \mathrm{ml}$ olarak ve triptofan düzeyi ise belirgin bir şekilde $13.80 \mathrm{mg} / \mathrm{l}$ 'den $3.19 \mathrm{mg} / 1$ ye azaldığı görülmüştür. Arttırılmış melatonin konsantrasyonu nedeniyle fermente edilmiş portakallı içecek ürününün yeni fonksiyonel gıda olarak kabul edilmiştir.

Yapılan bir diğer çalışmada, biradaki melatonin düzeyi ile ilgili çalışmalarında laboratuvar koşullarına ürettikleri birada $333 \mathrm{pg} / \mathrm{mL}$ melatonin ve $5 \%$ alkol oranı tespit edilmiştir. Ticari biralar ile karşılaştırdıklarında alkol oranı aynı olmasına rağmen melatonin düzeyini 3 kat daha fazla bulunmuştur. Bu durum ticari bira üretiminde 1sıl işlem ve dilüsyon proseslerinin daha agresif olmasına ve katkı maddelerine bağlanmıştır. Melatoninin arpa konsantre şırasında bulunduğu ve alkol fermantasyonu sırasında mayalar tarafından sentezlendiği belirtilmiştir [48].

Ekstra virgin zeytin yağında melatonin düzeyi rafine zeytinyağı ve ayçiçek yağına göre daha yüksek olduğu belirtilmiştir. Sızma zeytinyağı, rafine zeytin yağı ve ayçiçek yağı melatonin içeriği bakımından karşılaştırılmıştır. Isıl işlem ve herhangi bir kimyasal işlemden geçmeyen sızma zeytinyağında en fazla melatonin tespit edilmiştir. Çalışmada melatonin düzeyi sızma zeytinyağında (Toscano orijinli) $108 \pm 17.3 \mathrm{pg} / \mathrm{ml}$, rafine zeytin yağında $53 \pm 5.6 \mathrm{pg} / \mathrm{ml} \mathrm{ve}$ ayçiçek yağında $50 \pm 12.2 \mathrm{pg} / \mathrm{ml}$ olarak tespit edilmiştir [49].

Süte uygulanan UHT prosesinin sütteki melatonin içeriğini etkilemediği belirtilmiştir. İnek sütündeki melatonin konsantrasyonu üzerinde aydınlığın etkisi diğer faktörlere göre daha fazladır. Daha yüksek melatonin konsantrasyonları, gece süresinin daha uzun olduğu kış aylarında gece sağımında elde edilmiştir. Süpermarketlerde satışa sunulan UHT ve işlenmiş sütün melatonin konsantrasyonu ile çiğ sütün melatonin düzeyleri birbirine benzer bulunmuştur [37].

Geleneksel dut yaprağı çayının taze, yeşil ve siyah formu karşılaştırılmıştır. Taze dut yaprağı çayında en yüksek melatonin düzeyi tespit edilirken çay yapımındaki yüksek 1sıl işlemin melatonin miktarını azalttığ1 görülmüştür. Ayrıca dut yaprağı yeşil çayı ve dut yaprağı siyah çaylarının melatonin içeriği açısından aralarında anlamlı bir fark olmadığı ( $p>0.05)$ belirtilmiştir. Bu durum çay işleme sırasında ağartma işleminin, melatonin degredasyonu için kritik bir faktör olmadığ1 sonucunu getirmiştir [35].

Hem meyvelerde hem de meyve türevli ürünlerdeki melatonin konsantrasyonundaki farklılıklar, melatoninin 1şığa karşı düşük stabilitesine ve oksidatif strese karşı yüksek hassasiyetine bağlı olduğu görülmektedir [28]. Ayrıca meyve sularındaki serbest melatonin, meyve matrisine entegre olduğu durumdan 1şıkla bozunmaya daha duyarlı olduğu sonucuna varılmaktadır [43].

Ekmek hamur fermantasyonu ve ekmek pişirme sırasında melatonin ve melatonin izomerlerinin oluşumu incelenmiştir. Hamur örneklerinde melatonin izomerleri fermentasyon önce ve sonrası sırasılyla $4.02 \mathrm{ng} / \mathrm{g}$ ve $16.71 \mathrm{ng}$ /g olarak tespit edilmiştir [50].

Çiğ ve kavrulmuş findıklarda melatoninin öncü maddesi olan triptofan düzeyini karşılaştıran çalışmada kavurma işleminin serbest ve bağlı triptofan düzeyini etkilemediği belirtilmiştir [51].

\section{Melatonin biyoyararlılığı}

Biyoyararlılık, herhangi bir besin öğesinin vücutta emilen ve hücrede kullanılabilen düzeyidir. Bu düzey, besin öğesinin yapısına ve konsantrasyonuna, taşıyıcı gıdanın bileşimine, bu gıdanın sindirilme süresine, kişinin sağlık durumuna ve tüketilen gıdanın içinde bulunan besin öğelerinin interaksiyonuna bağlıdır [52]. Melatonince zengin gıdalar tüketildiğinde kandaki melatonin konsantrasyonu ve üredeki melatonin metaboliti olan 6 sülfatoksimelatonin 
oldukça yüksek olduğu bildirilmektedir. Melatonin çok hızlı metabolize olmaktadır. İnsanlarda yarılanma ömrü, eksojen uygulamadan sonra 10-60 dakika arasında değişmektedir [5].

Yapılan bir çalışmada ananas, portakal ve muzun serumdaki melatonin konsantrasyon ve antioksidan kapasitesine etkisi araştırılmıştır. On iki sağlıklı kişiden bu meyveleri tüketmeden önce ve sonra olmak üzere alınan kan örneklerinde plazma melatonin 60 dakika sonra 32 to $48 \mathrm{pg} / \mathrm{mL}$ ve 131 dakika sonra $145-151 \mathrm{pg} / \mathrm{mL}$ ve 180 dakika sonra hızla düştüğü $50 \mathrm{pg} / \mathrm{mL}$ den daha az olduğu tespit edilmiştir. Antioksidan kapasite ve serum melatonin konsantrasyonu arasında pozitif korelasyon olduğu belirtilmiştir [26].

Yapılan araştırmada, ceviz tüketen ratlarda serum melatonin konsantrasyonunun arttığı ve kandaki artan melatonin düzeyinin artan antioksidan kapasiteyle korelasyonlu olduğu belirtilmiş̧ir [41].

Melatonin kullanım dozajı istenilen etkiye bağlıdır. Hedef replacement terapi ise oral melatonin alımı 0.1; 0.5 mg aralı̆̆ında olup plazma konsantrasyonu 100;500 pg/ml olmaktadır. Melatonine bağlı uyku bozuklukları genellikle 1.0 ile $5.0 \mathrm{mg}$ oral melatonin ile tedavi edilmektedir [53].

Bitki bazlı gıdalardaki melatoninin biyoyararlanımı, gündüz seviyesini etkilemektedir ve tabiki sebze, meyve ve tahıl ürünleri bakımından zengin diyetlerin sağlıksal yararları ile açıklanabilmektedir [5].

Biradan alınan melatoninin biyoyararlanımının besin takviyelerinden alınan melatoninin dozu ile doğru orantılı olduğu bulunmuştur. Ayrıca, birada bulunan melatonin, insan serumunun toplam antioksidan aktivitesine katkıda bulunduğu ve insan vücudunu genel oksidatif stresten koruyabildiği bildirilmiş̧tir [1].

Diyetle melatonin alımı, günlük alınan diğer biyoaktif fitokimyasallarla (polifenoller) sinerji içinde hareket ederek, insanlarda tıbbi bitkilerin ve sağlıklı gıdaların sağlığı geliştirici etkilerini en üst düzeye çıkarmaya yardımcı olmaktadır. Endojen ve eksojen olarak edinilmiş melatonin arasında hiçbir fark olmadığı için, insanlardaki diyet katkısını değerlendirmek çok zordur [9].

\section{Sonuc}

Melatonin, bağışıklık sistemini güçlendirici, antioksidan, anti-inflamatuar, sirkadiyen düzenleyici, kanser gelişmesini engelleyici, antipsikotik gibi birçok biyoaktiviteye sahip önemli bir hormondur. Gıda ve sağlık ilişkisi yaşamın en önemli bütünleyicisidir. Melatonin ve öncü maddesi triptofan birçok gıdada tanımlanmıştır. Melatonin içeren gıda tüketiminin insan serumunda melatonin düzeyini artırdığını gösteren birçok çalışma mevcuttur. Ancak her geçen gün fonksiyonel yeni ürünler tüketime sunulmakta ve üretimde novel teknolojiler uygulanmaktadır. Özellikle bu ürünlerde proseslerin melatonin düzeyi ve biyoyararlılığı üzerine etkisinin araştırıldığı çalışmalara ihtiyaç vardır. Ayrıca melatonin takviyeli fonksiyonel ürünlerin geliştirilmesi teşvik edilmeli ve sağlıklı beslenmede yer almalıdır.

\section{Kaynaklar}

[1] Juhnevica- Radenkova, K., Moreno, D. A., Ikase, L., Drudze, I., \& Radenkovs, V. (2020). Naturally occurring melatonin: Sources and possible ways of its biosynthesis. Comprehensive Reviews in Food Science and Food Safety, 19(6), 4008-4030.

[2] Yilmaz, C., \& Gökmen, V. (2020). Neuroactive compounds in foods: Occurrence, mechanism and potential health effects. Food Research International, 128, 108744.

[3] Atasoy, N. (2019). Melatonin ve Antioksidan Etkileri. Düzce Üniversitesi Sağllk Bilimleri Enstitüsü Dergisi, 9(3), 196-201.

[4] Garaulet, M., Qian, J., Florez, J. C., Arendt, J., Saxena, R., \& Scheer, F. A. (2020). Melatonin effects on glucose metabolism: time to unlock the controversy. Trends in Endocrinology \& Metabolism, 31(3), 192-204.

[5] Nabavi, S. M., Nabavi, S. F., Sureda, A., Xiao, J., Dehpour, A. R., Shirooie, S., ... \& Daglia, M. (2019). Antiinflammatory effects of Melatonin: A mechanistic review. Critical reviews in food science and nutrition, 59(sup1), S4-S16.

[6] Chen, G., Huo, Y., Tan, D. X., Liang, Z., Zhang, W., \& Zhang, Y. (2003). Melatonin in Chinese medicinal herbs. Life sciences, 73(1), 19-26.

[7] Kleszczyński, K., Slominski, A. T., Steinbrink, K., \& Reiter, R. J. (2020). Clinical trials for use of melatonin to fight against COVID-19 are urgently needed. Nutrients, 12(9), 2561.

[8] Favero, G., Franceschetti, L., Buffoli, B., Moghadasian, M. H., Reiter, R. J., Rodella, L. F., \& Rezzani, R. (2017). Melatonin: Protection against age-related cardiac pathology. Ageing Research Reviews, 35, 336-349.

[9] Salehi, B., Sharopov, F., Fokou, P. V. T., Kobylinska, A., Jonge, L. D., Tadio, K., ... \& Iriti, M. (2019). Melatonin in medicinal and food plants: Occurrence, bioavailability, and health potential for humans. Cells, 8(7), 681.

[10] Shneider, A., Kudriavtsev, A., \& Vakhrusheva, A. (2020). Can melatonin reduce the severity of COVID-19 pandemic?. International reviews of immunology, 39(4), 153-162.

[11] Özçelik, F., Erdem, M., Bolu, A., \& Gülsün, M. (2013). Melatonin: Genel özellikleri ve psikiyatrik bozukluklardaki rolü. Psikiyatride Güncel Yaklaşımlar, 5(2), 179-203. 
[12] Öztürk, G., Akbulut, K. G., \& Güney, Ş. (2020). Melatonin, aging, and COVID-19: Could melatonin be beneficial for COVID-19 treatment in the elderly?. Turkish journal of medical sciences, 50(6), 1504-1512.

[13] Karunanithi, D., Radhakrishna, A., Sivaraman, K. P., \& Biju, V. M. N. (2014). Quantitative determination of melatonin in milk by LC-MS/MS. Journal of food science and technology, 51(4), 805-812.

[14] Esteban-Zubero, E., López-Pingarrón, L., Alatorre-Jiménez, M. A., Ochoa-Moneo, P., Buisac-Ramón, C., RivasJiménez, M., ... \& Reiter, R. J. (2017). Melatonin's role as a co-adjuvant treatment in colonic diseases: A review. Life sciences, $170,72-81$.

[15] Anderson, G., \& Reiter, R. J. (2020). Melatonin: roles in influenza, Covid- 19, and other viral infections. Reviews in medical virology, 30(3), e2109.

[16] Sehirli, A. O., Sayiner, S., \& Serakinci, N. (2020). Role of melatonin in the treatment of COVID-19; as an adjuvant through cluster differentiation 147 (CD147). Molecular biology reports, 1-5.

[17] Essa, M. M., Hamdan, H., Chidambaram, S. B., Al-Balushi, B., Guillemin, G. J., Ojcius, D. M., \& Qoronfleh, M. W. (2020). Possible role of tryptophan and melatonin in COVID-19. International Journal of Tryptophan Research, 13: 1-2. DOI: 10.1177/1178646920951832

[18] Yakupoğlu, G., Köklü, Ş., \& Korkmaz, A. (2018). Bitkilerde melatonin ve üstlendiği görevler. Tarim ve Doga Dergisi, 21(2), 264.

[19] Molik, E., Bonczar, G., Żebrowska, A., Misztal, T., Pustkowiak, H., \& Zięba, D. (2011). Effect of day length and exogenous melatonin on chemical composition of sheep milk. Archives Animal Breeding, 54(2), 177-187.

[20] Deng, B., Xia, C., Tian, S., \& Shi, H. (2021). Melatonin reduces pesticide residue, delays senescence, and improves antioxidant nutrient accumulation in postharvest jujube fruit. Postharvest Biology and Technology, 173, 111419.

[21] Üstündağ, H., Şentürk, E., \& Gül, M. (2020) Melatonin and Hyperthyroidism. Arch Basic Clin Res, 2(2): 59-64. DOI: $10.5152 / A B C R .2020 .03$.

[22] Atasoy, Ö. B., \& Erbaş, O. (2017). Melatonin hormonunun fizyolojik etkileri. İstanbul Bilim Üniversitesi Florence Nightingale Tip Dergisi, 3(1), 52-62.

[23] Meng, X., Li, Y., Li, S., Zhou, Y., Gan, R. Y., Xu, D. P., \& Li, H. B. (2017). Dietary sources and bioactivities of melatonin. Nutrients, 9(4), 367.

[24] Macit, M. G., \& Köse, Y. B. (2015). Medicinal plants used for folk medicine in Oltu (Erzurum/Turkey). [Biological Diversity and Conservation, 8(2), 74-80.

[25] Çalişkan, U. K., Ceylan, A. K. A., \& Emrah, B. O. R. (2017). Melatonin in edible and non-edible plants. Turkish Journal of Pharmaceutical Sciences, 14(1), 75.

[26] Sae- Teaw, M., Johns, J., Johns, N. P., \& Subongkot, S. (2013). Serum melatonin levels and antioxidant capacities after consumption of pineapple, orange, or banana by healthy male volunteers. Journal of pineal research, 55(1), 58-64.

[27] Stürtz, M., Cerezo, A. B., Cantos-Villar, E., \& Garcia-Parrilla, M. C. (2011). Determination of the melatonin content of different varieties of tomatoes (Lycopersicon esculentum) and strawberries (Fragaria ananassa). Food Chemistry, 127(3), 1329-1334.

[28] Feng, X., Wang, M., Zhao, Y., Han, P., \& Dai, Y. (2014). Melatonin from different fruit sources, functional roles, and analytical methods. Trends in Food Science \& Technology, 37(1), 21-31.

[29] Johns, N. P., Johns, J., Porasuphatana, S., Plaimee, P., \& Sae-Teaw, M. (2013). Dietary intake of melatonin from tropical fruit altered urinary excretion of 6-sulfatoxymelatonin in healthy volunteers. Journal of agricultural and food chemistry, 61(4), 913-919.

[30] Pereira, N., Naufel, M. F., Ribeiro, E. B., Tufik, S., \& Hachul, H. (2020). Influence of dietary sources of melatonin on sleep quality: A review. Journal of food science, 85(1), 5-13.

[31] Özen, İ. T., \& Ekşi, A. (2016). Melatonin and serotonin content of the main sour cherry varieties and commercially produced sour cherry concentrates. European International Journal of Science and Technology, 5(4), 57-64.

[32] Rodriguez-Naranjo, M. I., Gil-Izquierdo, A., Troncoso, A. M., Cantos-Villar, E., \& Garcia-Parrilla, M. C. (2011). Melatonin is synthesised by yeast during alcoholic fermentation in wines. Food Chemistry, 126(4), 16081613.

[33] Milagres, M. P., Minim, V. P., Minim, L. A., Simiqueli, A. A., Moraes, L. E., \& Martino, H. S. (2014). Night milking adds value to cow's milk. Journal of the Science of Food and Agriculture, 94(8), 1688-1692.

[34] Arnao, M. B., \& Hernández-Ruiz, J. (2018). Phytomelatonin, natural melatonin from plants as a novel dietary supplement: sources, activities and world market. Journal of Functional Foods, 48, 37-42.

[35] Pothinuch, P., \& Tongchitpakdee, S. (2011). Melatonin contents in mulberry (Morus spp.) leaves: effects of sample preparation, cultivar, leaf age and tea processing. Food chemistry, 128(2), 415-419.

[36] Tan, D. X., Zanghi, B. M., Manchester, L. C., \& Reiter, R. J. (2014). Melatonin identified in meats and other food stuffs: potentially nutritional impact. Journal of pineal research, 57(2), 213-218.

[37] Romanini, E. B., Volpato, A. M., dos Santos, J. S., de Santana, E. H. W., de Souza, C. H. B., \& Ludovico, A. (2019). Melatonin concentration in cow's milk and sources of its variation. Journal of Applied Animal Research. 
[38] Zieliński, H., Szawara-Nowak, D., \& Wiczkowski, W. (2017). Determination of melatonin in bakery products using liquid chromatography coupled to tandem mass spectrometry (LC-MS/MS). Chemical Papers, 71(6), 1083-1089.

[39] Kocadağlı, T., Yılmaz, C., \& Gökmen, V. (2014). Determination of melatonin and its isomer in foods by liquid chromatography tandem mass spectrometry. Food chemistry, 153, 151-156.

[40] Ramakrishna, A., Giridhar, P., Sankar, K. U., \& Ravishankar, G. A. (2012). Melatonin and serotonin profiles in beans of Coffea species. Journal of pineal research, 52(4), 470-476.

[41] Reiter, R. J., Manchester, L. C., \& Tan, D. X. (2005). Melatonin in walnuts: influence on levels of melatonin and total antioxidant capacity of blood. Nutrition, 21(9), 920-924.

[42] Riga, P., Medina, S., García-Flores, L. A., \& Gil-Izquierdo, Á. (2014). Melatonin content of pepper and tomato fruits: Effects of cultivar and solar radiation. Food chemistry, 156, 347-352.

[43] Pranil, T., Moongngarm, A., \& Loypimai, P. (2020). Influence of pH, temperature, and light on the stability of melatonin in aqueous solutions and fruit juices. Heliyon, 6(3), e03648.

[44] Fernández-Cruz, E., Álvarez-Fernández, M. A., Valero, E., Troncoso, A. M., \& García-Parrilla, M. C. (2017). Melatonin and derived L-tryptophan metabolites produced during alcoholic fermentation by different wine yeast strains. Food chemistry, 217, 431-437.

[45] Meng, J. F., Shi, T. C., Song, S., Zhang, Z. W., \& Fang, Y. L. (2017). Melatonin in grapes and grape-related foodstuffs: A review. Food chemistry, 231, 185-191.

[46] Mena, P., Gil-Izquierdo, Á., Moreno, D. A., Martí, N., \& García-Viguera, C. (2012). Assessment of the melatonin production in pomegranate wines. LWT-Food Science and Technology, 47(1), 13-18.

[47] Fernández- Pachón, M. S., Medina, S., Herrero- Martín, G., Cerrillo, I., Berná, G., Escudero- López, B., ... \& Gil- Izquierdo, A. (2014). Alcoholic fermentation induces melatonin synthesis in orange juice. Journal of pineal research, 56(1), 31-38.

[48] Garcia- Moreno, H., Calvo, J. R., \& Maldonado, M. D. (2013). High levels of melatonin generated during the brewing process. Journal of pineal research, 55(1), 26-30.

[49] de la Puerta, C., Carrascosa-Salmoral, M. P., García-Luna, P. P., Lardone, P. J., Herrera, J. L., FernándezMontesinos, R., ... \& Pozo, D. (2007). Melatonin is a phytochemical in olive oil. Food Chemistry, 104(2), 609612.

[50] Yılmaz, C., Kocadağlı, T., \& Gokmen, V. (2014). Formation of melatonin and its isomer during bread dough fermentation and effect of baking. Journal of agricultural and food chemistry, 62(13), 2900-2905.

[51] Taş, N. G., Yılmaz, C., \& Gökmen, V. (2019). Investigation of serotonin, free and protein-bound tryptophan in Turkish hazelnut varieties and effect of roasting on serotonin content. Food Research International, 120, 865871.

[52] Özge, K. U. R. T., \& Sedef, E. L. (2011). Biyoaktif bir gıda bileşeni L-karnitin: Beslenme ve sağlık açısından önemi ve biyoyararlılığı. TÜBAV Bilim Dergisi, 4(2), 97-102.

[53] Amaral, F. G. D., \& Cipolla-Neto, J. (2018). A brief review about melatonin, a pineal hormone. Archives of endocrinology and metabolism, 62(4), 472-479. 